\title{
Analysis of Invasive Techniques Used in Chronic Pain Management in Our Clinic: Evaluation of The First Year
}

\author{
Kliniğimizde Kronik Ağrı Tedavisi İçin Uygulanan Girişimsel Tekniklerin Analizi: \\ İlk Yıl Değerlendirmesi
}

Serbülent Gökhan Beyaz

Sakarya University Medical School, Department Of Anesthesiology, Sakarya, Turkey

\begin{abstract}
Purpose: We aimed to identify the services provided by our institute during one year after its inauguration reviewing the medical records of the patients given invasive pain management, and therefore, we aimed to bring forward the similarities and differences between our data and the results of pain studies performed both in Turkey and worldwide.

Method: Among 4104 patients who applied to the clinic for chronic pain treatment during the first year after inauguration of the pain clinic in 2009, those performed invasive techniques were reviewed. The invasive procedures were divided into two groups-minor and major interventions. The simple invasive procedures that were performed to the ambulatory patients in policlinics were called minor interventions and those, which were performed with the help of fluoroscopy in the operating room were considered as major invasive procedures.

Results: Totally 1299 patients were treated with invasive techniques. Of these invasive methods, 492 (37.88\%) were minor and 807 $(62.12 \%)$ were major invasive procedures. Among all invasive procedures, the most common one was the lumbar epidural injection followed by trigger point injection and intra-articular knee joint injection (numbers of patients were 364, 316 and 238, respectively).

Conclusion: Since the number of patients suffering from chronic pain becomes greater as average life-span increases in Turkey, inauguration of new centers, which offer invasive pain management and enhancing the number of physicians practicing such treatment procedures, would be a prospect for the patients suffering from pain.
\end{abstract}

Keywords: Invasive procedure, chronic pain, pain center, treatment, Turkey.

Aplication: 18.05.2012 Accepted: 22.09.2012
Özet

Amaç: Kuruluşunun birinci yılında girişimsel ağrı tedavisi uygulanan hastaların kayıtlarını inceleyerek verilen hizmetleri saptamak, böylelikle hem Türkiye' de hem de dünyada yapılan diğer ağrı çalışmaları ile benzerlik ve farklılıkları ortaya koymayı amaçladık.

Metod: 2009 yılında kurulan ağrı kliniğinin ilk yılında kronik ağrı tedavisi için kliniği ziyaret eden 4104 hasta içerisinden girişimsel invaziv teknik kullanılanlar tarandı. Invaziv girişimler minor ve major olarak iki gruba ayrıldı. Poliklinikte uygulanan basit invaziv işlemler minor, ameliyathanede fluroskopi eşliğinde yapılanlar ise major olarak adlandırıldı.

Bulgular: toplam 1299 hastaya girişimsel invaziv teknik uygulandı. Bunları 492 (\%37.88)' si minör, 807 (\%62.12)' si major invaziv teknikti. Tüm girişimsel işlemler içerisinde en sık yapılan ilk 3 işlem sırasıyla lomber epidural enjeksiyon, tetik nokta enjeksiyonu ve diz içi enjeksiyonlar olarak belirlendi (hasta sayıları sırasıyla, 364, 316 ve 238). Sonuç: Türkiye' de yaşam süresinin uzaması ile kronik ağrı çeken hasta sayısı artacağından girişimsel ağrı tedavisi uygulayan merkezlerin açılması ve yine bu tür tedavileri uygulayan hekim sayısının artıııması ağrı çeken hastalar için bir umut olacaktır.

Anahtar Kelimeler: Girişimsel işlem, kronik ağrı, ağrı merkezi, tedavi, Türkiye

Başvuru Tarihi: 18.05.2012 Kabul Tarihi: 22.09.2012 


\section{Introduction}

Pain always exists throughout the history of humanity and there is no person who does not suffer from pain in any period of his/her lifespan. Epidemiological studies indicate that chronic pain is an important public health issue. Continuity of chronic pain, appealing to a healthcare center on a regular basis, continuous necessity of analgesic drug use, restrictions in daily life activities, being a cause of missed working days or unemployment explain how great the extent of this problem could be. ${ }^{1}$

The prevalence of pain increases with age. ${ }^{2}$ In contrast to common belief, the prevalence of pain has been reported less often, because older people have a misbelieve that pain is naturally resulted from aging, so that they do treat themselves with simple analgesics and do not consult to a physician. Joint pain and neuralgias are the most common pain types among people with advanced age. ${ }^{3}$ On the other hand, the figures underestimates the prevalence than actual status among the patients with cancer, since these patients are afraid of disease progression. The majorities of older people have significant pain problems and are treated inadequately. Of older cancer patients, $25-40 \%$ suffer daily sensation of pain and $21-30 \%$ of these patients do not take any analgesic medicine or the drugs which they use remain insufficient. ${ }^{4}$

In the United States, more than 40 million people are affected by pain related to muscle-skeletal system. In USA, it is estimated that 500000 to 1 million spine surgeries and 2 to 5 million invasive procedures are performed every year. ${ }^{5}$ There are more than 400 million working days lost in each year. In USA, the number of patients affected by this disorder raised from 49 million to 54 million in the period between 1991 and $1995 .{ }^{6}$ In USA, it is estimated that 70 million people visit their physicians' offices and other 130 million ambulatory patients visit hospitals and emergency units because of spine- and muscle-skeletal system-related disorders. ${ }^{7}$

The pain centers providing invasive pain management techniques should document clinical effects and efficacy of invasive procedures performed, should increase the quality of patient care, improve the cost-effectiveness ratio, and should demonstrate outcomes. The aim of this retrospective study is to identify the services provided by our institute throughout one year after its inauguration reviewing the medical records of the patients performed invasive pain management, and therefore, we aimed to bring forward the similarities and differences between our data and the results of pain studies performed both in Turkey and worldwide.

\section{Method}

After receiving the approval of the university ethics committee, we reviewed retrospectively the records of the patients performed invasive procedures using the sisoft patient identification program established by our hospital's data processing center among 4104 patients presenting to the Pain Policlinic at Ordu University Educational and Research Hospital between 1 January 2009 to 31 December 2009. Using sisoft patient identification program, we first reached the records of the day patients. Then, the patients, who were performed invasive procedures in the policlinic or operating room, were selected using the computer printout data. The written medical records of these patients were collected from the hospital archives and reviewed. The medical documents of the patients undergoing interventions were analyzed. Age, gender, weight and the type of intervention were recorded.

All invasive procedures were considered if there was no response to pharmacologic therapies for at least 2 weeks of duration. We excluded the patients with coagulopathy, pregnant women, the patients with active infection, those having known allergies against the drugs or contrast substances used and the patients who refused the invasive procedure offered.

The invasive procedures were divided into two groupsminor and major interventions. The simple invasive procedures that were performed to the ambulatory patients in policlinics were called minor interventions and those, which were performed with the help of fluoroscopy in 
the operating room were considered as major invasive procedures. All invasive procedures were performed by the author of this article. All interventions were performed under sterile conditions. The patients who had major interventions were hospitalized for 4 hours after procedures.

\section{Statistics}

The SPSS 12.0 software program was used for statistical analysis. Descriptive statistical method including frequency analysis, cross-table analysis, percentage, mean, standart devation were calculated. $\mathrm{p}<0.05$ was accepted as significant.

\section{Results}

Of 4104 patients who presented to the policlinic between 1 January 2009 to 31 December 2009, 1299 (31.65\%) patients were performed invasive procedures. Among all invasive procedures, the most common one was the lumbar epidural injection followed by trigger point injection and intra-articular knee joint injection (numbers of patients were 364, 316 and 238, respectively).

Minor invasive procedures were performed to 807 patients (Table 1). Of these patients, 468 (58\%) were women and 339 (42\%) were men; the average age was $48.26 \pm 14.13$ (range, 14-63), the average weight was $65.27 \pm 14.61$. Among minor invasive procedures, the most commonly performed one was the trigger point injection (316 patients, 39.15\%). The second most frequently performed procedure was the knee joint injection (238 patients, 29.5\%).

Major invasive procedures were performed to 492 patients (Table 2). Of these patients, 346 (70\%) were women and $146(30 \%)$ were men; the average age was $58.26 \pm 10.94$ (range, 21-89), the average weight was $67.21 \pm 11.02$. In the group of patients performed major invasive procedures, number of female gender was predominanced. Among the major invasive procedures, the most commonly performed one was the lumbar and cervical epidural injection (364 [28.03\%] and 68 [5.24\%] patients, respectively). The most common location of pain was the lumbar region of the spine (385 patients, $29.3 \%$ ) followed by head-and-neck (73 patients, 5.6\%), pelvis (34 patients, 2.8\%) and thoracic areas (4 patients, $0.3 \%)$.

Among 4104 patients presenting to the policlinic, almost all patients who did not respond to medical treatment appealed to the pain policlinic because of musculoskeletal pain. The most often performed invasive procedure was the trigger point injection. The most common location of pain was the lumbar region in all patients. Thirteen patients were performed invasive procedures because of cancer pain.

Table 1: The list of minor invasive procedures and number of patients, (n, \%)

\begin{tabular}{|c|c|}
\hline Trigger point injections & $316(24.32 \%)$ \\
\hline The knee of intra-articular injections & $238(18.32 \%)$ \\
\hline The shoulder of intra-articular injections & $51(3.93 \%)$ \\
\hline Plantar fasciitis injections & $12(0.93 \%)$ \\
\hline Tendinitis (tendon around of injections) & $109(8.4 \%)$ \\
\hline Epin calcanei injections & $7(0.54 \%)$ \\
\hline Achilles tendon of injections & $2(0.15 \%)$ \\
\hline $\begin{array}{l}\text { Entrapment neuropathies (carpal tunnel syn- } \\
\text { drome, cubital tunnel syndrome, piriformis } \\
\text { syndrome) injections }\end{array}$ & $29(2.23 \%)$ \\
\hline Trigger finger injections & $3(0.23 \%)$ \\
\hline $\begin{array}{l}\text { Lateral and medial epicondyle around of } \\
\text { injections }\end{array}$ & $13(1 \%)$ \\
\hline Occipital neuralgia caused of injections & $1(0.07 \%)$ \\
\hline Metatarsalgia caused injections & $24(1.85 \%)$ \\
\hline Dequervain's tenosynovitis & $2(0.15 \%)$ \\
\hline Total & $807(62.12 \%)$ \\
\hline
\end{tabular}

\section{Discussion}

The cost of musculoskeletal system disorders tends to increase gradually. In 1997, it reached up to $1-2.5 \%$ of national income in 5 industrialized countries (Australia, Canada, France, United Kingdom and USA). The medical expenses relating to arthritis and other rheumatic disea- 
ses were 233,5 billion dollars in 1997, whilst this figure raised to 321,8 billion dollars in 2003. It is estimated that 3,4-13,2 billion dollars of these expenditures are occupational and that it exceeds the cost relating to asthma, pulmonary diseases, renal and neurologic disorders. The indirect cost is the expenditure other than medical treatments, e.g. loss of labor, home care, childcare, medical equipments, arrangements at home setting which are needed because of disablement status. ${ }^{8}$

Table 2: The list of major invasive procedures and number of patients.

\begin{tabular}{|l|c|}
\hline Intercostal block & $2(0.15 \%)$ \\
\hline Impar ganglion block & $1(0.07 \%)$ \\
\hline Stellate ganglion block & $3(0.23 \%)$ \\
\hline Lumbar facet median nevre block & $11(0.85 \%)$ \\
\hline Tunneled epidural catheter (thoracal / lumbar) & $3(2 / 1)(0.23 \%)$ \\
\hline The hip intra-articular injections & $2(0.15 \%)$ \\
\hline Lumbar epidural injections & $364(28.03 \%)$ \\
\hline Cervical epidural injections & $68(5.24 \%)$ \\
\hline Sacrococcsigeal ligament injections & $3(0.23 \%)$ \\
\hline Caudal epidural neuroplasty & $9(0.7 \%)$ \\
\hline Sacroiliac joint injections & $24(1.85 \%)$ \\
\hline Temporomandibular joint injections & $2(0.15 \%)$ \\
\hline Total & $492(37.88 \%)$ \\
\hline
\end{tabular}

The most rapidly increasing segment of global population consists of elderly people. It is estimated that the global number of people aged 65 years and over will be increased to 1.3 billion by 2040. According to 2008 census data, the number of people aged 65 years and older is 38.9 million in USA, these people from $12.8 \%$ of general population. Moreover, 5.7 million of this elderly people are aged 85 years and over. ${ }^{6}$ The factors affecting the prevalence of pain among elderly people involve female gender, chronic diseases with gradually increasing frequency with age (e.g. musculoskeletal system disorders), independent trouble walking. In addition, low level of education results in incapacity to cope with chronic pain or to seek for medical care among elderly people. The studies focusing on identifying and resolving the factors causing pain in older people are of importance to reduce the prevalence of pain among elderly people. ${ }^{9}$ In a study, the prevalence of pain was reported to be $64 \%$ among elderly people. ${ }^{10}$ In another study, it was reported that the prevalence of pain was $72.7 \%$ among individuals aged 65-74 years, who were living in home setting and it was denoted that the complaint of pain was more common among women in comparison with men. ${ }^{11}$ In the present study, major invasive procedures were most commonly performed to female patients, and the most common body area at which the intervention was done was lumbar region (385 patients, 29.3\%). In our clinic, most of the patients $(70 \%)$ who were performed major invasive procedures were female patients. Low back pain is triggered by both physical strain during domestic activities of housewives (lifting heavy objects, inappropriate posture, etc.) and the advances in agriculture and animal husbandry on the basis of climatic conditions of particularly the Black Sea region. We think that housewives appeal more often to our policlinic spending more time for their complaint of pain in comparison with working women.

Chronic pain is of importance since it impairs the quality of life of the patient, emerges the need for a caregiver, and affects the patient's independency. Pain relief allows the patient to do daily living activities e.g. preparing and eating foods, taking a shower, going to bathroom, wearing, doing simple domestic activities, walking, shopping, and praying. Hence, chronic pain management should include modalities reducing the perception of pain and improving the functions of patient. ${ }^{6} \mathrm{~A}$ vast majority of patients presenting to our pain clinic had chronic musculoskeletal system pain restricting their daily activities and they were seeking a solution without surgery. When pharmacologic therapies are insufficient and inefficacious, these patients cannot be treated and become chronic because of scarcity of physicians performing invasive procedures in this region.

In a review of the database of a private insurance agency, it was found that $15 \%$ of annual expenditures for drugs were spent for pain-related medicines in 2003 and 2004. There are few data about intra-articular treatment. In a 
study, it was estimated that 6-month cost (injection, arthrocentesis, and fee for doctor's office) varied from 852 to 1840 dollars in 2006. Joint replacement treatments become increased gradually. It is estimated that hip arthroplasty will be increased by $174 \%$ and knee arthroplasty by $673 \%$ from 2005 to 2030 . In a project about health expenditures, total cost of knee and hip arthroplasties was estimated to be 15,6 billion dollars in $2007 .{ }^{12}$

Pampati et al. ${ }^{13}$ reported that invasive procedures were performed to 1149 of 1499 patients (76.65\%) by single physician within 3 years. Karaman and Kavak ${ }^{14}$ denoted that in 2008, 2460 patients were admitted in their pain clinic established in 2002 and the number of minimal invasive procedures was 769 (31.26\%). In a study demonstrating the advances in interventional invasive procedures between 1997 and 2006 in all USA states with pain clinics, Laxmaiah et al. ${ }^{15}$ reported that epidural procedures increased by $145 \%$, neuroplasty increased by $19 \%$, facet joint interventions increased by $160 \%$, and sacroiliac joint interventions increased by $107 \%$. In Turkey, it is not known how many invasive pain procedures are done, because there is scarce number of pain clinics and insufficient data. In the first year after inauguration of the pain clinic, 4104 patients were examined and 1299 of them were performed invasive procedures by the author. Lower proportion of patients performed invasive procedures in our country can be linked to weak multidisciplinary and interdisciplinary approaches. In addition, excessive increase in patient population in a brief period can be related to satisfaction of patients presenting to the pain clinic, the nearest pain clinic 3-4 hours away, difficulties in reaching to the single pain specialist in the region, opiophobia of the physicians working in this region against red and green prescription drugs, positive statements of cured patients with their partners, friends and relatives. We expect an extreme increase in the type and number of invasive pain management techniques performed in our pain clinic.

In the United Kingdom, the most common cause of the complaint of chronic pain was showed to be the low back pain. ${ }^{16}$ Portenoy et al. ${ }^{17}$ reported hip and lower extremity pain $(47 \%)$, low back pain $(40 \%)$, head and neck pain
(28\%), and shoulder and upper extremity pain (24\%). In Turkey, there are few or no studies about the prevalence of pain among adults and invasive procedures to relieve pain. In a study, Ayvat et al. ${ }^{1}$ reported totally 130 patients to whom they performed minimal invasive procedures. In that study, the authors reported only the causes of chronic pain, but they did not state detailed information about minimal invasive techniques used. Karaman and Kavak ${ }^{14}$ reported that 769 patients were performed minimal invasive procedures in a one-year analysis performed 6 years after inauguration of the pain clinic. Analyzing our data, we recognized that in the first year after inauguration of our pain clinic, the number of both ambulatory and hospitalized patients exceeded the patient numbers of other clinics (4104 visited to polyclinic patients, 1299 hospitalized patients) and it was found that most of these patients had non-cancer chronic pain such as low back pain, neck pain. These groups usually consist of patients not responding to medical therapy or not willing to undergo surgery. Several kinds of interventional modalities can provide benefits for a majority of such patients.

Invasive pain modalities can be helpful to identify underlying reasons of pain and to make a definitive diagnosis. These modalities reduce the need for multiple and high-dose drug use, therefore contribute to avoid from undesired adverse effects of high-dose drug use. Nerve blockage is one of the most commonly used methods by specialized physicians for pain management. This method is helpful not only for diagnosis but also for prognosis, preemptive analgesia, and sometimes for descriptive treatment. Other methods involve chemical neurolysis, radiofrequency lesion, cryoneurolysis, neuroaugmentation, and neuroaxial drug administration. ${ }^{6}$

In conclusion, interventional invasive pain management should be performed when pharmacologic therapies are insufficient. Since the number of patients suffering from chronic pain becomes greater as average life-span increases in Turkey, establishment of new centers, which offer invasive pain management and enhancing the number of physicians practicing such treatment procedures, would be a prospect for the patients suffering from pain. 


\section{Kaynaklar}

1. Ayvat PU, Aydin ON, Oğurlu M. [Sociodemographic properties and pain prevalence of patients applying to the Algology Department polyclinic of Adnan Menderes University Medical Faculty]. Agri. 2011; 23(1):28-39.

2. Crook J, Rideout E, Browne G. The prevalence of pain complaints in a general population. Pain. 1984; 18(3):299-314.

3. Badley EM, Tennant A. Changing profile of joint disorders with age: findings from a postal survey of the population of Calderdale, West Yorkshire, United Kingdom. Ann Rheum Dis. 1992; 51(3):366-71.

4. Cleeland CS. Undertreatment of cancer pain in elderly patients. JAMA. 1998 17; 279(23):1914-5.

5. Manchikanti L, Staats PS, Singh V, Schultz DM, Vilims BD, Jasper JF et al. Evidence-based practice guidelines for interventional techniques in the management of chronic spinal pain. Pain Physician. 2003; 6(1):3-81.

6. Kaye AD, Baluch A, Scott JT. Pain management in the elderly population: a review. Ochsner J. 2010; 10(3):179-87.

7. Rogers MT. Development of interdisciplinary spinal interventional pain centers. Pain Physician. 2003; 6(4):527-35.

8. Bitton R. The economic burden of osteoarthritis. Am J Manag Care 2009; 15:230-5.

9. Şimşek TT, Yumin ET, Öztürk A, Serel M, Yumin M. [The Relationship Between Pain and Health Status, Mobility and Daily Life Activities in Community-Living elderly Healthy Volunteers]. Turk J Phys Med Rehab 2011; 57: 216-20.
10. Sawyer P, Bodner EV, Ritchie CS, Allman RM. Pain and pain medication use in community-dwelling older adults. Am J Geriatr Pharmacother 2006;4:316-24.

11. Miro J, Paredes S, Rull M, Queral R, Miralles R, Nieto R, et al. Pain in older adults: A prevelance study in the Meditarranean region of Catalonia. Eur J Pain 2007;11:83-92.

12. Bodur H. [Current review on osteoarthitis in Turkey and the world; epidemiology and socioeconomic aspect]. Turkish Journal of Geriatrics 2011 14; Suppl 1: 7-14.

13. Pampati S, Cash KA, Manchikanti L. Accuracy of diagnostic lumbar facet joint nerve blocks: a 2-year follow-up of 152 patients diagnosed with controlled diagnostic blocks. Pain Physician. 2009; 12(5):855-66.

14. Karaman $\mathrm{H}$, Kavak GÖ. [An annual case analysis of our pain clinic]. Pam Med J 2010; 3(1):17-22.

15. Manchikanti L, Singh V, Pampati V, Smith HS, Hirsch JA. Analysis of growth of interventional techniques in managing chronic pain in the Medicare population: a 10-year evaluation from 1997 to 2006. Pain Physician. 2009; 12(1):9-34.

16. Elliott AM, Smith BH, Penny KI, Smith WC, Chambers WA. The epidemiology of chronic pain in the community. Lancet. 1999 9;354(9186):1248-52.

17. Portenoy RK, Ugarte C, Fuller I, Haas G. Population-based survey of pain in the United States: differences among white, African American, and Hispanic subjects. J Pain. 2004; 5(6):317-28. 